\title{
Insulin-like growth factors and cancer: no role in screening. Evidence from the BUPA study and meta-analysis of prospective epidemiological studies
}

\author{
JK Morris',', LM George', T Wu' and NJ Wald' \\ 'Centre for Environmental and Preventive Medicine, Wolfson Institute of Preventive Medicine, Barts and The London Queen Mary's School of Medicine \\ and Dentistry, Charterhouse Square, London ECIM 6BQ, UK
}

Insulin-like growth factor-I (IGF-I), insulin-like growth factor-2 (IGF-2), and insulin-like growth factor binding protein-3 (IGFBP-3) were measured in frozen serum samples from 1051 men with cancer and 3142 controls in a nested case-control study from the British United Provident Association (BUPA) study cohort and associations with 14 cancers were examined, including prostate, colorectal, and lung. A meta-analysis of studies on these three cancer sites was also conducted. In the meta-analysis the odds ratio between the highest quartile IGF-I group and the lowest quartile group was 1.31 (95\% confidence interval (Cl): I.03-I.67) for prostate, I.37 (I.05-1.78) for colorectal and I.02 (0.80-1.3I) for lung cancer, and for IGF-2 it was $0.72(0.36-1.44)$ for prostate and 1.95 ( $1.26-3.00)$ for colorectal cancer. Results from the BUPA study were consistent with the estimates from the other studies. There were no statistically significant associations with IGFBP-3 and any of the cancer sites considered. Our results suggest that IGF- I, IGF-2, and IGFBP-3 measurements have no value in cancer screening, although IGF-I and IGF-2 may be of aetiological significance in relation to colorectal and prostate cancer.

British Journal of Cancer (2006) 95, II2 - I17. doi:I0.1038/sj.bjc.6603200 www.bjcancer.com

(c) 2006 Cancer Research UK

Keywords: cancer screening; meta-analysis; cohort studies; insulin-like growth factors; epidemiology

Prospective studies have shown that higher circulating concentrations of insulin-like growth factor 1 (IGF-1), insulin-like growth factor 2 (IGF-2), and insulin-like growth factor binding protein-3 (IGFBP-3) are associated with an increased risk of prostate cancer, colorectal cancer, and premenopausal breast, and ovarian cancer (Lukanova et al, 2002; Renehan et al, 2004). Aetiological importance has been attributed to these associations, and it has been suggested that they may be of value in screening for these cancers.

We here report results on measurements of IGF-1, IGF-2, and IGFBP-3 from the British United Provident Association (BUPA) prospective study, based on 1051 new cases of cancer at 14 different cancer sites, and we combine the results on prostate, colorectal, and lung cancer with those from published studies in a meta-analysis.

\section{METHODS}

The BUPA study is a prospective study of 21520 professional men aged 35-64 years resident in Britain who attended the BUPA medical centre in London between 1975 and 1982 for a routine medical examination. Serum samples were stored at $-40^{\circ} \mathrm{C}$. The men were flagged at the National Health Service Central Register in Southport, permitting automatic notification of death (with the certified cause) and cancer incidence by the Office for National

*Correspondence: Dr JK Morris; E-mail: j.k.morris@qmul.ac.uk

Received 24 February 2006; revised 2 May 2006; accepted 5 May 2006
Statistics. Further information on the causes of death was obtained by writing to each certifying doctor. This analysis is based on a maximum follow-up of 15 years and is restricted to those cancers for which at least 10 cases occurred. In this period, there were 1059 men for whom we had a cancer notification. For each case, three controls (who were still alive and for whom we did not have a cancer notification) were selected; they were matched for age and duration of storage of the serum sample each to one year.

In 2003 the frozen serum samples were retrieved. The sample was insufficient for eight cases; these and the corresponding controls were excluded. The sample was also insufficient in 11 controls, leaving 1051 cases, 1040 cases with three controls and 11 cases with two controls, 3142 controls in total. IGF-1, IGF-2 and IGFBP-3 were measured using DSL-10-5600 ACTIVE IGF-I, DSL10-9100 ACTIVE IGF-2 and DSL-10-6600 ACTIVE IGFBP-3 enzyme-linked ImmunoSorbent Assay (ELISA) kits. The serum samples from the cancer cases and their matched controls were systematically analysed together in the same analytical batch with blinding so that the case was not identifiable. The samples from the cases (and the corresponding controls) were analysed in groups according to the type of cancer.

To determine if freezing the samples and storing them at $-40^{\circ} \mathrm{C}$ affected the levels of IGF-1 and IGF-2, a separate set of samples was analysed. Forty samples from the same BUPA cohort that the cases and controls came from (collected between 1975 and 1982) were randomly selected, five from each year of the study. Forty fresh samples were obtained from men aged 35-64 years resident in Britain who attended the BUPA medical centre in London in 2003. The median levels from the samples prior to 1982 compared with 
the median in 2003 were $1 \%$ (95\% confidence interval $(\mathrm{CI}):-12 \%$ to $+25 \%)$ higher for IGF-1 $(P=0.66)$ and $-6 \%(95 \% \mathrm{CI}:-18 \%$ to $+4 \%)$ lower for IGF-2 $(P=0.93)$, indicating that storing the serum at $-40^{\circ} \mathrm{C}$ for over 20 years did not reduce the levels of IGF-1 or IGF-2.

The statistical analysis of the BUPA data was carried out as follows: Pearson correlation coefficients were used to examine the associations between IGF-1, IGF-2, IGFBP-3 and age within the controls. The case-control matching was preserved for each cancer site, rather than analysing the cases of a particular cancer with all the controls. Conditional logistic regression models were used to calculate odds ratios (OR) for cancer for quartile levels of the markers, which takes account of the matching. Quartile cut points were determined on the distribution of control subjects for each cancer site separately. To determine if there was a significant linear association with risk of cancer the original markers (that is the continuous measurements not categorised into quartiles) were entered into the conditional logistic regression model. Body mass index (BMI), smoking and alcohol consumption were all investigated as possible confounders for each cancer site separately. BMI was analysed as a continuous measure. There were seven smoking categories (nonsmokers, exsmokers, pipe and cigar smokers and four categories of cigarette smokers (115 day $^{-1}, 15-24$ day $^{-1}, 25-34$ day $^{-1}$ and $35+$ day $\left.^{-1}\right)$ ) and five alcohol categories (Teetotal, 'Social', 1-2 units per day, 3-6 units per day and $6+$ units per day).

The meta-analysis was carried out as follows: We searched MEDLINE and EMBASE from January 1996 to December 2005 combining the keywords IGF* $^{*}$ and cancer to find published prospective studies on IGF-1, IGF-2 and IGFBP-3 and cancer. We searched citation lists from review articles and previously published meta-analyses excluding breast and ovarian cancers, as our data are only on men. Meta-analyses were performed on the results using a random effects model for the published results from prospective studies (using a nested case-control design). The odds of cancer occurring in the top quartile of the marker compared with the bottom quartile were combined. For studies that gave the odds according to quintiles these were adjusted to quartile values. For prostate, colorectal and lung cancers we included the results of the present (BUPA) study in the meta-analysis. To assess for publication bias, we examined the funnel plots for each cancer site and tested if the regression of study estimate with study precision was significant. We investigated all sources of heterogeneity with subgroup analyses and also investigated the effects of adjusting IGF-1 for IGFBP-3 levels and IGFBP-3 for IGF-1 levels as is often perormed. Potential sources of heterogeneity investigated were: year of publication, type of sample, average time from sample collection to cancer diagnoses and study location. There was no evidence of publication bias for any of the cancer sites.

\section{RESULTS}

Table 1 gives details of the study population including the number of men according to cancer site and the mean age of the men at the time of entry into the BUPA study and gives the medians and interquartile ranges for IGF-1, IGF-2 and IGFBP-3 according to case-control status and, as has been observed in other studies, IGF-1 and IGFBP-3 were moderately correlated $(r=0.5)$ and both declined with age ( $r=-0.18$ for IGF- 1 and age and $r=-0.12$ for IGFBP-3 and age). IGF-2 was less highly correlated with IGFBP-3 $(r=0.29)$ and age $(r=-0.10)$.

\section{Prostate, colorectal and lung cancer results from the BUPA study}

Table 2 shows the odds of cancer according to quartiles (fourths) of IGF-1, IGF-2 and IGFBP-3 for prostate, colorectal and lung
Table I BUPA study: characteristics at the time of screening of men who developed cancer within 15 years and controls who did not

\begin{tabular}{|c|c|c|}
\hline & Controls & Cases \\
\hline Number of men & 3142 & $105 \mid$ \\
\hline Mean age (years) & 52.4 & 52.4 \\
\hline $\begin{array}{l}\left.\text { Median IGF-I ( } \mathrm{ng} \mathrm{ml}^{-1}\right)\left(25^{\text {th }}-75 \text { th }\right. \\
\text { centiles) }\end{array}$ & $124(90-160)$ & $122(88-164)$ \\
\hline $\begin{array}{l}\text { Median IGF-2 (ng ml } \\
\text { centiles) }\end{array}$ & $636(517-767)$ & $639(5 \mid 4-772)$ \\
\hline $\begin{array}{l}\text { Median IGFBP-3 }\left(\mu \mathrm{g} \mathrm{ml}^{-1}\right) \text { (25th-75th } \\
\text { centiles) }\end{array}$ & $3.2(2.7-3.8)$ & $3.2(2.6-3.8)$ \\
\hline $\begin{array}{l}\text { Median time till diagnosis in cases } \\
\text { (years) }\end{array}$ & & 9.7 \\
\hline $\begin{array}{l}\text { Proportion cases diagnosed within } 3 \\
\text { years }\end{array}$ & & $8 \%$ \\
\hline $\begin{array}{l}\text { Proportion cases diagnosed within } 10 \\
\text { years }\end{array}$ & & $53 \%$ \\
\hline \multicolumn{3}{|l|}{ Number of men by site of cancer } \\
\hline Prostate & 423 & $|4|$ \\
\hline Colon and rectum & 440 & 147 \\
\hline Lung & 498 & 167 \\
\hline Bladder & 234 & 78 \\
\hline Lymphoma & 166 & 56 \\
\hline Stomach & 123 & 41 \\
\hline Oesophagus & 123 & 41 \\
\hline Skin & 123 & 41 \\
\hline Pancreas & $1 \mid 4$ & 38 \\
\hline Brain & 113 & 38 \\
\hline Kidney & 110 & 37 \\
\hline Leukaemia & 102 & 34 \\
\hline Mouth and pharynx & 39 & 13 \\
\hline Larynx & 38 & 13 \\
\hline Other/Multicancer & 496 & 166 \\
\hline
\end{tabular}

cancer. There were no statistically significant associations between any of the cancers and any of the serum markers but the wide confidence did not exclude relative risks of up to 3.4 .

\section{Results of the meta-analysis}

Table 3 and Figure 1 shows the meta-analysis of IGF-1, IGF-2 and IGFBP-3 results from published prospective studies and the results from the present study (there were no published studies on IGF-2 and lung cancer). This analysis includes all the studies in the earlier analysis by Renehan et al (2004) together with eight others (Lacey et al, 2001; Wakai et al, 2002; Nomura et al, 2003; Woodson et al, 2003; Stattin et al, 2004; Chen et al, 2005; Meyer et al, 2005; Platz et al, 2005). The meta-analysis was restricted to data from prospective studies to minimise any effects of the cancer on the measurements made.

Prostate cancer The risk of developing prostate cancer for men in the top quartile of IGF-1 compared with the bottom quartile was 1.31 (95\%CI: 1.03-1.67; Table 3). There was no significant heterogeneity between studies $(P=0.21)$. There was no association between the risk of prostate cancer and IGF-2 (OR $=0.72 ; 95 \% \mathrm{CI}$ : $0.36-1.44$; Table 3 ) or IGFBP-3 levels (OR $=1.05$; $95 \% \mathrm{CI}$ : 0.82 1.35; Table 3).

In the present study prostate-specific antigen (PSA) was also measured on the 141 men who developed prostate cancer and their controls at the same time as measuring IGF-1. The odds ratio of prostate cancer in the highest quartile compared with the lowest quartile was very high (OR $=3195 \% \mathrm{CI}: 10-92)$, demonstrating by comparison the modest association with IGF-1, in spite of it being statistically significant. 
Table 2 BUPA study: odds of prostate, colorectal, and lung cancer according to quartiles of serum levels of IGF-I, IGF-2 and IGFBP-3 within the first I5 years of follow-up (follow-up being the time between sample collection and diagnosis)

\begin{tabular}{|c|c|c|c|c|c|c|}
\hline Site of cancer & Analyte & \multicolumn{5}{|c|}{ Adjusted odds ratios ${ }^{a}$} \\
\hline \multicolumn{7}{|l|}{ Prostate } \\
\hline & |GF-| & 1 & 0.96 & 0.61 & $1.37(0.76-2.49)$ & 0.62 \\
\hline & IGF-2 & 1 & 1.18 & 1.49 & $1.47(0.77-2.81)$ & 0.19 \\
\hline & IGF-I & 1 & 1.20 & 1.39 & $1.10(0.56-2.18)$ & 0.65 \\
\hline & IGF-2 & I & 1.70 & 1.84 & $1.59(0.67-3.75)$ & 0.40 \\
\hline & IBFBP-3 & I & 0.90 & 1.06 & $0.72(0.37-1.37)$ & 0.46 \\
\hline \multicolumn{7}{|l|}{ Lung } \\
\hline & |GF-I & I & 1.00 & 1.23 & $1.21(0.62-2.35)$ & 0.45 \\
\hline & IGF-2 & I & 1.21 & 1.22 & $0.82(0.39-1.73)$ & 0.61 \\
\hline
\end{tabular}

${ }^{a}$ The odds ratios were adjusted for age by matching and were also adjusted: smoking for lung cancer and smoking, alcohol and body mass index for colon and rectum.

Colorectal cancer There was a positive association $(\mathrm{OR}=1.37$ $95 \%$ CI: $1.05-1.78)$ with IGF-1 and no evidence of heterogeneity between the studies $(P=0.68)$. There was also a positive association ( $\mathrm{OR}=1.95$ 95\%CI: $1.26-3.00)$ with IGF-2 and again no evidence of heterogeneity between the studies $(P=0.87)$. For IGFBP-3 there was no significant association $(\mathrm{OR}=0.98(0.64-$ $1.51)$, however, there was significant heterogeneity between studies $(P=0.02)$. None of the subgroup analyses explained the heterogeneity between the studies.

Lung cancer There was no indication of an association between IGF-1 and lung cancer $(\mathrm{OR}=1.02(0.80-1.31))$ nor between IGFBP-3 and lung cancer $(\mathrm{OR}=0.98(0.61-1.58))$. However, there was significant heterogeneity between the studies for IGFBP-3 $(P=0.01)$. The study by Spitz et al (2002) differed from the other studies in that the cohort was of men who were heavy smokers and asbestos workers. Excluding this study from the analyses resulted in an odds ratio $=0.84(0.52-1.35)$ with a reduction in the heterogeneity $(P=0.07)$ and there was evidence that the study differed significantly from all the other studies $(P=0.002)$.

\section{BUPA study results on 11 other site-specific cancers}

The results are presented according to tertile group (not quartile groups) because of the smaller numbers (Table 4). Cancers of the oesophagus, mouth and pharynx were significantly associated with lower levels of IGF-1 and cancer of the lymphoma was significantly associated with lower levels of IGF-2. There were no statistically significant associations between the 11 cancer sites with IGFBP-3. The three associations are likely to be spurious results due to multiple significance testing. There were no significant results when all cancers were considered together for any of the markers.

\section{DISCUSSION}

Our results show that none of the growth factors measured (IGF1, IGF2 or IGFBP3) have any value in cancer screening in men. The strength of the associations are too weak for them to have any useful effect in distinguishing people who will and will not develop cancer at any of the sites studied. Relative risks of about two between the top and bottom quartile groups translate into a sensitivity (or detection rate) of less than $10 \%$ for a $95 \%$ specificity (5\% false-positive rate) (Wald et al, 1999). In contrast, the corresponding odds ratio for prostate cancer between the top and bottom quartile groups of PSA measured in this study was 31 , corresponding to a sensitivity of over $30 \%$ for a $95 \%$ specificity, high enough for a potential screening test (Wald et al, 1999). Combining the growth factors with other markers into a screening test is also unlikely to be worthwhile, as in order to obtain a reasonable screening performance over 20 tests with relative risks of about two would be required (Wald et al, 2005).

Results relating to three female cancers, breast, ovary and endometrium, were not included in our meta-analyses as they were discussed in a recent meta-analysis by Renehan et al (2004) (breast) and two papers by Lukanova et al $(2002,2004)$ (ovary and endometrium). Renehan et al (2004) reported a relative risk of premenopausal breast cancer between the top and bottom quartile of IGF-1 of 2.08 (1.37-3.15), with no significant associations for postmenopausal breast cancer. Lukanova et al (2002, 2004) reported a nonsignificant positive association between IGF-1and premenopausal ovarian cancer $(R R=1.90(0.63-5.75))$ with no other associations approaching statistical significance. The strengths of the associations between these female cancers and the growth factors measured are not higher than any observed in our study. There are no data relating to cervix cancer, but given the overall pattern of results it would be surprising if cervix cancer was an exception. We therefore are confident that the general conclusion that none of the growth factors measured (IGF1, IGF2 or IGFBP3) have any value in cancer screening can be extended to all the main cancers in men and women.

Our second conclusion is that one of the growth factors, IGF2, may be of aetiological significance in colorectal cancer. This was suggested by the results from the two previous studies and is now clarified by the meta-analysis including our own results on this growth factor. Statistically significant associations between IGF-1 and colorectal and prostate cancer may also be of aetiological significance, but the evidence is weaker.

This is the first report of a cohort study on associations with cancers in men other than prostate, colorectal and lung. Considering the small numbers of cancers diagnosed and the likely OR of around 1.5, this study has low power to detect significant associations in the less common cancers, but nonetheless there were no positive associations between any of the cancers and any of the markers. The value of this study is to enable the data to be included in future meta-analyses needed to have the statistical power to investigate possible associations. We restricted the analysis of the BUPA data to 15 years of follow-up since in the 
Table 3 Meta-analysis: prospective studies of IGF-I, IGF-2 and IGFBP-3 and cancer of the prostate, colon and rectum and lung, ordered by mean time till diagnosis

\begin{tabular}{|c|c|c|c|c|c|c|c|c|c|}
\hline \multirow{2}{*}{ Study } & \multirow{2}{*}{$\begin{array}{l}\text { No. of } \\
\text { cases }\end{array}$} & \multirow{2}{*}{$\begin{array}{l}\text { No. of } \\
\text { controls }\end{array}$} & \multirow{2}{*}{ Gender } & \multirow{2}{*}{$\begin{array}{l}\text { Sample } \\
\text { medium }^{a}\end{array}$} & \multirow{2}{*}{$\begin{array}{l}\text { Adjust- } \\
\text { ments }^{b}\end{array}$} & \multirow{2}{*}{$\begin{array}{l}\text { Mean time } \\
\text { till diagnosis } \\
\text { (years) }\end{array}$} & \multicolumn{3}{|c|}{ Odds ratio highest quartile vs lowest quartile $(95 \% \mathrm{Cl})$} \\
\hline & & & & & & & IGF-I & IGF-2 & IGFBP-3 \\
\hline \multicolumn{10}{|l|}{ Prostate cancer } \\
\hline Platz et al (2005) & 462 & 462 & $\mathrm{~m}$ & $\mathrm{Pl}$ & & 2.2 & $1.37(0.92-2.03)$ & & $1.62(1.07-2.46)$ \\
\hline Chen et al (2005) & 174 & 175 & $\mathrm{~m}$ & $\mathrm{Pl}$ & & 3.4 & $0.67(0.37-1.25)$ & & $0.65(0.34-1.20)$ \\
\hline Stattin et al (2004) & 281 & 560 & $\mathrm{~m}$ & $\mathrm{Pl}$ & $b, s$ & 4.8 & $1.67(|.02-2.7|)$ & & $1.30(0.84-2.03)$ \\
\hline Meyer et al (2005) & 100 & 400 & $\mathrm{~m}$ & $\mathrm{Pl}$ & & 6.8 & $1.34(0.68-2.65)$ & $0.67(0.34-1.30)$ & $0.72(0.35-1.48)$ \\
\hline Chan et al (1998) & 152 & 152 & $\mathrm{~m}$ & $\mathrm{Pl}$ & $\mathrm{s}$ & 7 & $2.41(1.25-4.74)$ & $0.97(0.48-1.95)$ & $1.07(0.54-2.11)$ \\
\hline Harman et al (2000) & 72 & 127 & $\mathrm{~m}$ & Ser & & 9.2 & $1.65(0.71-3.86)$ & $0.24(0.10-0.59)$ & $0.71(0.30-1.66)$ \\
\hline Woodson et al (2003) & 100 & 400 & $\mathrm{~m}$ & Ser & b & 9.6 & $1.00(0.54-1.87)$ & & $0.71(0.36-1.39)$ \\
\hline Current study (BUPA) & $14 \mid$ & 423 & $\mathrm{~m}$ & Ser & & 10.4 & $1.37(0.76-2.49)$ & $1.47(0.77-2.8 \mathrm{I})$ & $1.40(0.77-2.55)$ \\
\hline Lacey et al (200I) & 30 & 60 & $\mathrm{~m}$ & Ser & & 14 & $0.70(0.2-2.3)$ & & I.I $(0.3-3.8)$ \\
\hline Total & 1512 & 2759 & & & & 5.4 & $1.31(1.03-1.67)$ & $0.72(0.36-1.44)$ & $1.05(0.82-1.35)$ \\
\hline & & & & & & & $\begin{array}{l}\text { Test for heterogeneity: } \\
P=0.21\end{array}$ & $\begin{array}{l}\text { Test for heterogeneity: } \\
P=0.0 \text { I }\end{array}$ & $\begin{array}{l}\text { Test for heterogeneity: } \\
P=0.19\end{array}$ \\
\hline \multicolumn{10}{|l|}{ Colorectal cancer } \\
\hline Giovannucci et al (2000) & 79 & 158 & $\mathrm{~F}$ & $\mathrm{Pl}$ & $a, b$ & $3^{c}$ & $1.21(0.52-2.81)$ & & $0.53(0.18-1.53)$ \\
\hline Palmqvist et al (2002) & 168 & 336 & M\&f & $\mathrm{Pl}$ & $\mathrm{s}, \mathrm{l}$ & 3.35 & $1.27(0.65-2.47)$ & & $1.23(0.68-2.22)$ \\
\hline Kaaks et al (2000); Hunt et al (2002) & 102 & 200 & $\mathrm{~F}$ & Ser & $\mathrm{s}, \mathrm{l}$ & 4.8 & $1.88(0.72-4.91)$ & $2.08(0.85-5.06)$ & $2.46(1.09-5.57)$ \\
\hline Probst-Hensch et al (200I) & 135 & 661 & M & Ser & $a, b, s$ & 6.1 & $1.52(0.82-2.85)$ & $2.09(1.14-3.82)$ & $1.72(0.91-3.25)$ \\
\hline Ma et al (1999) & 193 & 318 & M & $\mathrm{Pl}$ & $a, b, s$ & $9^{c}$ & $1.36(0.72-2.55)$ & & $0.47(0.23-0.95)$ \\
\hline Current study (BUPA) & 147 & 440 & M & Ser & $a, b, s$ & 9.6 & $1.10(0.56-2.18)$ & $1.59(0.67-3.76)$ & $0.72(0.37-1.37)$ \\
\hline Nomura et al (2003) & 282 & 282 & M & Ser & $a, b, s$ & 11 & $1.50(0.8-2.8)$ & & $0.80(0.4-1.6)$ \\
\hline Total & 1106 & 2395 & & & & 7.6 & $1.37(1.05-1.78)$ & $1.95(1.26-3.00)$ & $0.98(0.64-1.5 \mathrm{I})$ \\
\hline & & & & & & & Test for heterogeneity: & Test for heterogeneity: & Test for heterogeneity: \\
\hline & & & & & & & $P=0.68$ & $P=0.87$ & $P=0.02$ \\
\hline \multicolumn{10}{|l|}{ Lung cancer } \\
\hline London et al (2002) & 230 & 740 & M & Ser & s & 4 & $0.73(0.43-1.24)$ & & $0.56(0.30-1.03)$ \\
\hline Wakai et al (2002) & 194 & 9351 & $M \& f$ & Ser & $s, b$ & 5.2 & $1.17(0.78-1.77)$ & & $0.67(0.45-1.01)$ \\
\hline Spitz et al (2002) & 159 & 297 & M\&f & Ser & s & $6^{c}$ & $1.11(0.64-1.93)$ & & $1.67(0.96-2.92)$ \\
\hline Lukanova et al (200I) & 93 & 186 & $\mathrm{~F}$ & Ser & $b, s, l$ & 6.4 & $0.79(0.29-2.19)$ & & $0.90(0.36-2.25)$ \\
\hline Current study (BUPA) & 167 & 498 & $M$ & Ser & s & 9.0 & $1.21(0.62-2.35)$ & & $1.70(0.87-3.30)$ \\
\hline Total & 843 & 11072 & & & & 5.9 & $1.02(0.80-1.31)$ & & $0.98(0.61-1.58)$ \\
\hline & & & & & & & Test for heterogeneity: & & Test for heterogeneity: \\
\hline & & & & & & & $P=0.64$ & & $P=0.01$ \\
\hline
\end{tabular}

${ }^{\mathrm{a} P \mathrm{Pl}}=$ plasma, Ser = serum. ${ }^{\mathrm{B}} \mathrm{All}$ studies matched for age of cases. Other variables matched for are: a (alcohol consumption); b (body mass index); s (cigarette smoking); I (time since last food consumption); g(insulin and glucose). ${ }^{\mathrm{C}}$ Mean time till diagnosis estimated from the papers. 
IGF-1

Author and publication year

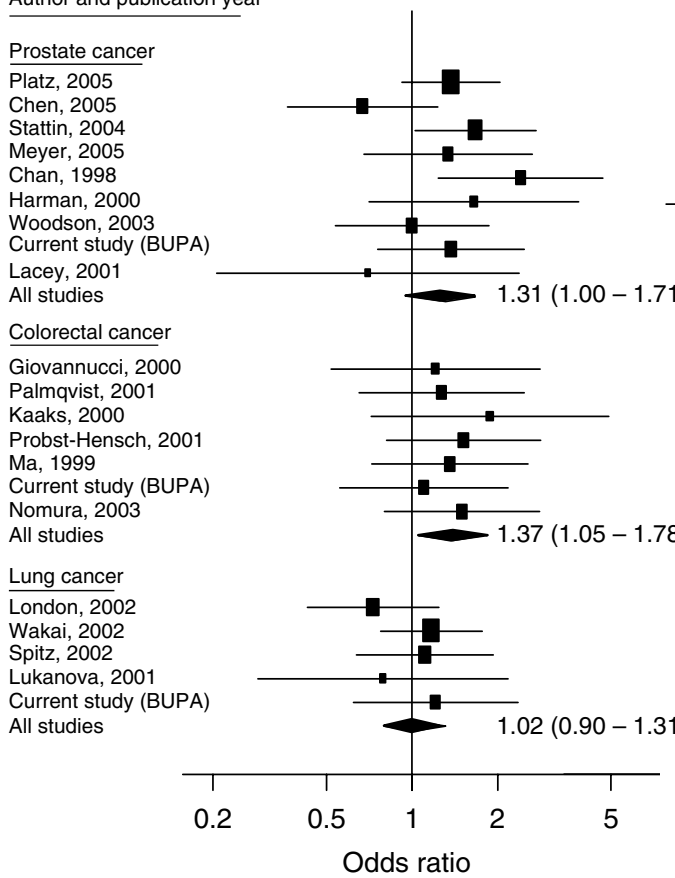

IGF-2

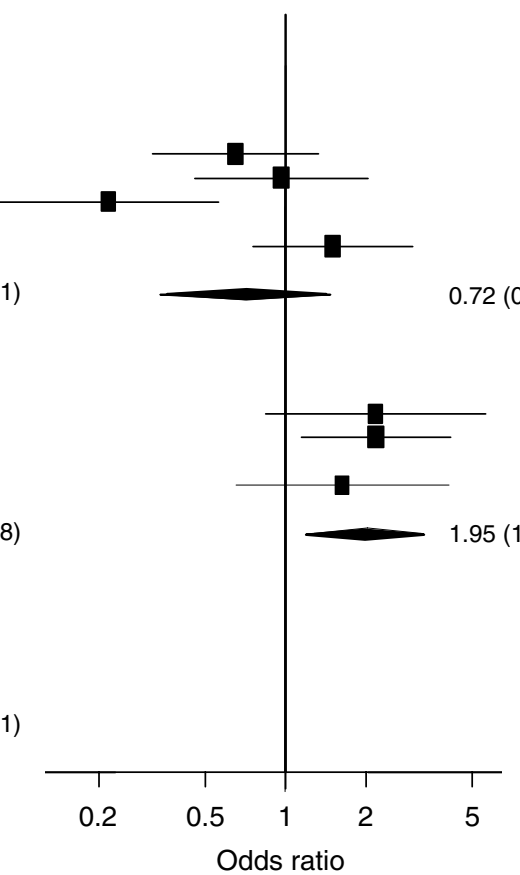

IGFBP-3

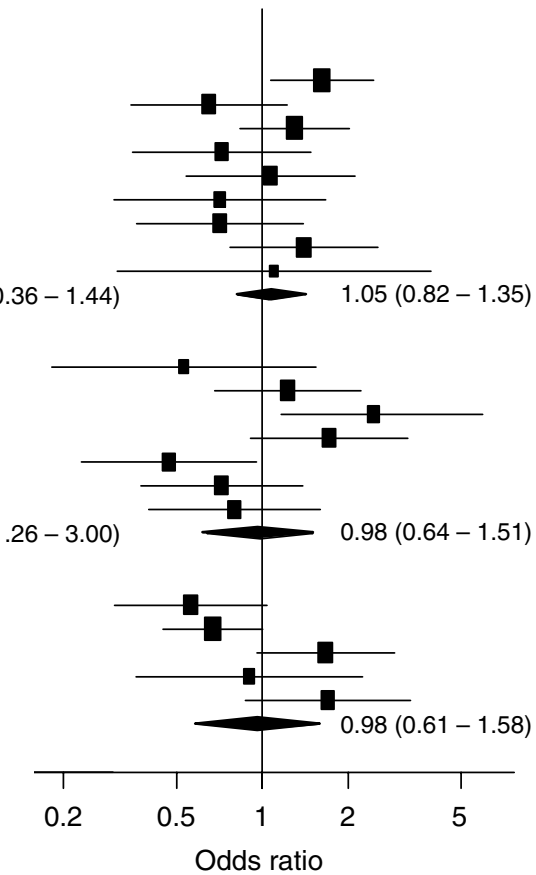

Figure I Prospective studies of IGF-I, IGF-2 and IGFBP-3 and prostate, colorectal and lung cancer. The studies are ordered (top down) by increasing average time interval between blood collection and cancer diagnosis.

Table 4 BUPA study: odds of cancer by tertile group of IGF-I, IGF-2 and IGFBP-3 for II common sites occurring during the first I5 years of follow-up (follow-up being the time between sample collection and diagnosis)

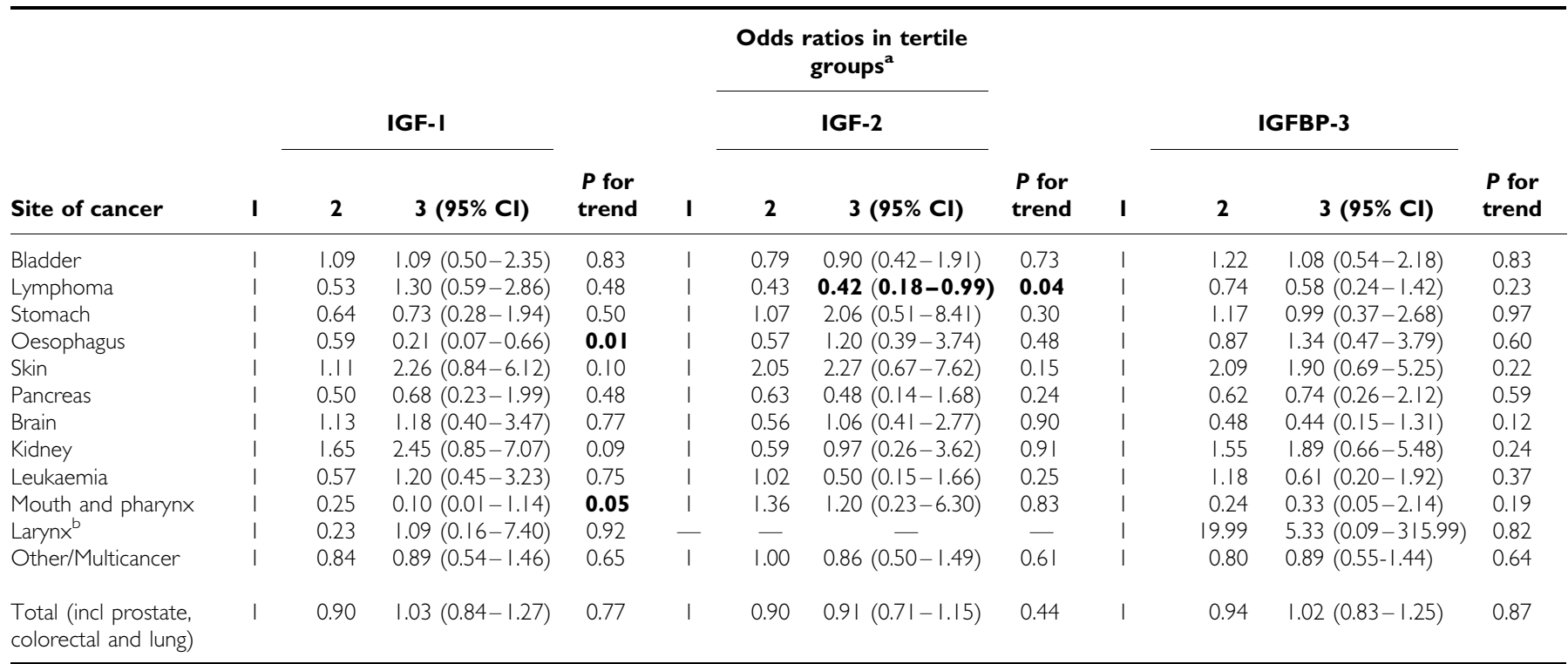

aThe odds ratios were adjusted for age by matching and were also adjusted for the following confounding factors in the statistical analysis according to site : smoking (pancreas,

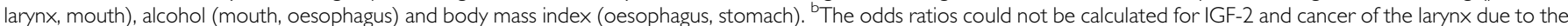
lack of heterogeneity of IGF-2 values amongst cases and controls.

other studies the meta-analysis had similar maximum lengths of follow up. The data were also available for a further seven years of follow-up, but their inclusion did not materially alter the results.

The published studies in the meta-analysis presented the odds for IGF-1 adjusted for IGFBP-3 values and the odds for IGFBP-3 adjusted for IGF-1. Our meta-analysis provides no evidence that IGFBP-3 is associated with cancer and therefore there is no reason to adjust IGF-1 values for IGFBP-3. Such an analysis yields similar estimates of the OR obtained for IGF-1 alone, confirming that it is of little or no value in increasing the strength of the association. 


\section{ACKNOWLEDGEMENTS}

We thank BUPA Foundation for their support and Diagnostic Systems Laboratories Inc. for performing all the biochemical analyses free of charge. This research is independent of both BUPA and DSL.

\section{REFERENCES}

Chan JM, Stampfer MJ, Giovannucci E, Gann PH, Ma J, Wilkinson P, Hennekens CH, Pollak MN (1998) Plasma insulin-like growth factor-I and prostate cancer risk: a prospective study. Science 279: $563-566$

Chen C, Lewis SK, Voigt L, Fitzpatrick A, Plymate SR, Weiss NS (2005) Prostate carcinoma incidence in relation to prediagnostic circulating levels of insulin-like growth factor 1, insulin-like growth factor binding protein 3, and insulin. Cancer 103: $76-84$

Giovannucci E, Pollak MN, Platz EA, Willett WC, Stampfer MJ, Majeed N, Colditz GA, Speizer FE, Hankinson SE (2000) A prospective study of plasma insulin-like growth factor-1 and binding protein-3 and risk of colorectal neoplasia in women. Cancer Epidemiol Biomarkers Prev 9: $345-349$

Harman SM, Metter EJ, Blackman MR, Landis PK, Carter HB (2000) Serum levels of insulin-like growth factor I (IGF-I), IGF-II, IFG-binding protein3 , and prostate-specific antigen as predictors of clinical prostate cancer. $J$ Clin Endocrinol Metab 85: 4258-4265

Hunt KJ, Toniolo P, Akhmedkhanov A, Lukanova A, Dechaud H, Rinaldi S, Zeleniuch-Jacquotte A, Shore RE, Riboli E, Kaaks R (2002) Insulin-like growth factor 2 and colorectal cancer risk in women. Cancer Epidemiol Biomarkers Prev 11: 901 - 905

Kaaks R, Toniolo P, Akhmedkhanov A, Lukanova A, Biessy C, Dechaud H, Rinaldi S, Zeleniuch-Jacquotte A, Shore RE, Riboli E (2000) Serum Cpeptide, insulin-like growth factor (IGF)-I, IGF-binding proteins, and colorectal cancer risk in women. J Natl Cancer Inst 92: 1592-1600

Lacey JV, Hsing AW, Fillmore CM, Hoffman S, Helzlsouer KJ, Comstock GW (2001) Null association between insulin-like growth factors, insulinlike growth factor-binding proteins, and prostate cancer in a prospective study. Cancer Epidemiol Biomarkers Prev 10: $1101-1102$

London SJ, Yuan J-M, Travlos GS, Gao Y-T, Wilson RE, Ross RK, Yu MC (2002) Insulin-like growth factor I, IGF-bindin protein 3, and lung cancer risk in a prospective study of men in China. J Natl Cancer Inst 94: 749754

Lukanova A, Toniolo P, Akhmedkhanov A, Biessy C, Haley NJ, Shore RE, Riboli E, Rinaldi S, Kaaks R (2001) A prospective study of insulin-like growth factor-I, IFG-binding proteins-1, -2 and -3 and lung cancer risk in women. Int J Cancer 92: 888-892

Lukanova A, Lundin E, Toniolo P, Micheli A, Akhemkhanov A, Rinaldi S, Muti P, Lenner P, Krogh V, Biessy C, Zeleniuch-Jacquotte A, Berrino F, Hallmans G, Riboli E, Kaaks R (2002) Circulating levels of insulin-like growth factor-1 and risk of ovarian cancer. Int J Cancer 101: 549-554

Lukanova A, Zeleniuch-Jacquotte A, Lundin E, Micheli A, Arslan AA, Rinaldi S, Muti P, Lenner P, Koenig KL, Bessy G, Krogh V, Riboli E, Shore RE, Stattin P, Berrino F, Hallmans G, Toniolo P, Kaaks R (2004) Prediagnostic levels of C-Peptide, IGF-1, IGFBP -1,-2 and -3 and risk of endometrial cancer. Int J Cancer 108: 262-268

Ma J, Pollak MN, Giovannucci E, Chan JM, Tao Y, Hennekens CH, Stampfer MJ (1999) Prospective study of colorectal cancer risk in men and plasma levels of insulin-like growth factor (IGF)-I AND IFG-binding protein-3. $J$ Natl Cancer Inst 91: 620-625

Meyer F, Galan P, Douville P, Bairati I, Kegle P, Bertrais S, Czernichow S, Hercberg S (2005) A prospective study of the insulin-like growth factor axis in relation with prostate cancer in the SU.VI.MAX trial. Cancer Epidemiol Biomarkers Prev 14: 2269-2272

Nomura AMY, Stemmermann GN, Lee J, Pollak MN (2003) Serum insulinlike growth factor 1 and subsequent risk of colorectal cancer among Japanese-American men. Am J Epidemiol 158: 424-431

Palmqvist R, Hallmans G, Rinaldi S, Biessy C, Stenling R, Riboli E, Kaaks R (2002) Plasma insulin-like growth factor 1, insulin-like growth factor binding protein 3 , and risk of colorectal cancer: a prospective study in northern Sweden. Gut 50: 642-646

Platz EA, Pollak MN, Leitzmann MF, Stampfer MJ, Willett WC, Giovannucci E (2005) Plasma inculin-like growth factor-1 and binding protein-3 and subsequent risk of prostate cancer in the PSA era. Cancer Causes Control 16: $255-262$

Probst-Hensch NM, Yuan J-M, Stanczyk FZ, Gao Y-T, Ross RK, Yu MC (2001) IGF-1, IFG-2 and IGF-3 in prediagnostic serum: association with colorectal cancer in a cohort of Chinese men in Shanghai. Br J Cancer 85: 1695 - 1699

Renehan AG, Zwahlen M, Minder C, O’Dwyer ST, Shalet SM, Egger M (2004) Insulin-like growth factor (IGF)-I, IFG binding protein-3, and cancer risk: systematic review and meta-regression analysis. Lancet 363: $1346-1353$

Spitz MR, Barnett MJ, Goodman GE, Thornquist MD, Wu X, Pollak M (2002) Serum insulin-like growth factor (IGF) and IGF-binding protein levels and risk of lung cancer: a case-control study nested in the $\beta$ carotene and retinol efficacy trial cohort. Cancer Epidemiol Biomarkers Prev 11: $1413-1418$

Stattin P, Rinaldi S, Biessy C, Stenman U-H, Hallmans G, Kaaks R (2004) High levels of circulating insulin-like growth factor-1 increase prostate cancer risk: a prospective study in a population-based nonscreened cohort. J Clin Oncol 22: 3104-3112

Wakai K, Ito Y, Suzuki K, Tamakoshi A, Seki N, Ando M, Ozasa K, Watanabe Y, Kondo T, Nishino Y, Ohno Y (2002) Serum insulin-like growth factors, insulin-like growth factor-binding protein-3, and risk of lung cancer death: a case-control study nested in the Japan Collaborative Cohort (JACC) Study. Jpn J Cancer Res 93: 1279-1286

Wald NJ, Hackshaw AK, Frost CD (1999) When can a risk factor be used as a worthwhile screening test? BMJ 319: $1562-1565$

Wald NJ, Morris JK, Rish S (2005) The efficacy of combining several risk factors as a screening test. J Med Screen 12: 197-201

Woodson K, Tangrea JA, Pollak M, Copeland TD, Taylor PR, Virtamo J, Albanes D (2003) Serum insulin-like growth factor I: tumor marker or etiologic factor? A prospective study of prostate cancer among Finnish men. Cancer Res 63: 3991 - 3994 